\title{
IMPACT OF ACIDIFICATION AND EUTROPHICATION ON MACROPHYTE COMMUNITIES IN SOFT WATERS IN THE NETHERLANDS I. FIELD OBSERVATIONS
}

\section{J.G.M. ROELOFS}

Laboratory of Aquatic Ecology, Catholic University, Nijmegen (The Netherlands)

(Accepted for publication 15 July 1983)

\begin{abstract}
Roelofs, J.G.M., 1983. Impact of acidification and eutrophication on macrophyte communities in soft waters in The Netherlands. I. Field observations. Aquat. Bot., 17 : 139-155.
\end{abstract}

During the last decades a strong decline has been noticed in the number of waters dominated by "Littorellion" species, mostly isoetids such as Lobelia dortmanna L., Isoetes lacustris L. and Littorella uniflora (L.) Aschers. Sixty-eight waters, which were known to be dominated by $L$. uniflora after 1950 were investigated. In $1980, L$. uniflora appeared to be absent or to have strongly decreased in 53 (78\%) of the waters. In 41 of them, Littorella had been replaced by submerged Juncus bulbosus L. and/or Sphagnum spp. These changes seem to have been caused by changed inorganic carbon budgets as a consequence of acidification.

In the remaining 12 waters, eutrophication of the water and/or sediment seems to be responsible for the changes in the plant communities. Enrichment with phosphate of the mineral sediment alone, leads to luxurious growth of submerged, rooted macrophyte species such as Myriophyllum alterniflorum DC and Ranunculus peltatus Schrank, whereas phosphate-enrichment of both sediment and water leads to luxurious growth of pleustophytes such as Riccia fluitans L. and Lemna minor L. in small, shallow waters, and to plankton bloom and luxurious growth of epiphytes in larger, deeper waters.

In these cases light limitation seems to be responsible for the disappearance or decline of the "Littorellion" species.

\section{INTRODUCTION}

During the past 20 years the deleterious effects of acid precipitation on aquatic and terrestrial ecosystems have become a growing problem. Reports from The First Intermational Symposium on Acid Precipitation and Forest Ecosystem (Dochinger and Seliga, 1975), the United Nations Conference of the Human Environment (Engstrom, 1971) and of the International Conference on the Impact of Acid Precipitation (Drablos and Tollan, 1980) emphasize the gravity of the phenomenon. 
Aquatic habitats appear to be very susceptible to the effects of acidification. The severe depletion of fish stocks and the decreased diversity of algae and invertebrates in many Swedish and Norwegian waters can be ascribed to the effects of acidification. It is only fairly recently that a few reports have been published which express alarm about acidifying waters on poorly buffered sediments in The Netherlands (van Dam and Kooyman-van Blokland, 1978; van Dam et al., 1981; van Zellem, 1981) and Belgium (Vangenechten et al., 1980).

The mechanisms of acidification, however, appear to be very complex and are not yet clearly understood. In many cases the impact of acidification cannot be ascribed to $\mathrm{pH}$ decrease alone. Brooktrout, Salvelinus fontinalis (Mitchell), for instance, seem to suffer mainly from toxic aluminium concentrations mobilized by increasing acidification, as they are able to tolerate substantial additions of sulphuric acid (Daye and Garside, 1975). It is also known that heavy metals are more toxic to algae at low pH (Voigt, 1979). Inhibition of nitrogen-turnover processes (Tamm et al., 1977; Alexander, 1980 ) and leaching (Stuanes, 1980) are likely to cause future nutrient deficiencies in forest ecosystems.

However, little is known about the impact of acidification on freshwater macrophytes. Grahn et al. (1974) and Grahn (1977) mention a suppression of isoetid species in Scandinavian waters by luxurious Sphagnum growth as a result of acidification of the water and Nilssen (1980) mentions a luxurious growth of Juncus bulbosus L. in acidified Scandinavian waters.

In The Netherlands there has been a dramatic decline in the number of stands belonging to the phytosociological alliance Littorellion during the last 30 years. These stands are characterized by isoetids, such as Littorella uniflora (L.) Aschers., Lobelia dortmanna L., Isoetes lacustris L., etc. (Schoofvan Pelt, 1973). These "Littorellion communities" mainly occurred in moorland pools, in small lakes and dune lakes on mineral sandy soils. It is precisely these poorly buffered waters that have become strongly acidified during the last decades (van Dam and Kooyman-van Blokland, 1978; van Dam et al., 1981). The coastal dune lakes appeared to be less susceptible to acidification, due to the higher content of calcium carbonate of the bottom.

Eutrophication has been generally considered to be the main cause of the decline of the Littorellion communities (Schoof-van Pelt, 1973; Westhoff et al., 1973; Westhoff, 1979; Pott, 1982; Wittig, 1982a,b; Wittig and Pott, 1982); Westhoff (1979) also mentioned inadequate maintenance in nature reserves as a secondary cause. Acidification was not mentioned by these authors as being a possible cause.

The present study was carried out in order to establish which part of the decline of the "Littorellion" communities can be ascribed to acidification, which part is due to eutrophication and possible other causes, and which changes in the composition of the macrophyte communities occur as a result of these processes. 


\section{STUDY SITES}

Sixty-eight low alkaline waters were selected, where, according to Schoofvan Pelt (1973), Westhoff et al. (1971) and H.M. van der Steeg, C. den Hartog, D.T.A. van der Ploeg, E. Weeda and J. Hofstra (personal communication), after 1950 a plant community occurred, in which Littorella uniflora was one of the dominant species.

Low alkaline waters in The Netherlands are restricted to the higher situated, poorly buffered, sandy soils in the southern and eastern part of the country and to the coastal region (Fig. 1). In the provinces of Noord Brabant, Limburg, Gelderland, Overijssel and Drenthe mainly moorland pools and some small lakes were studied and only dune pools in the province of Zuid-Holland and on the isles of Texel, Terschelling and Schiermonnikoog.

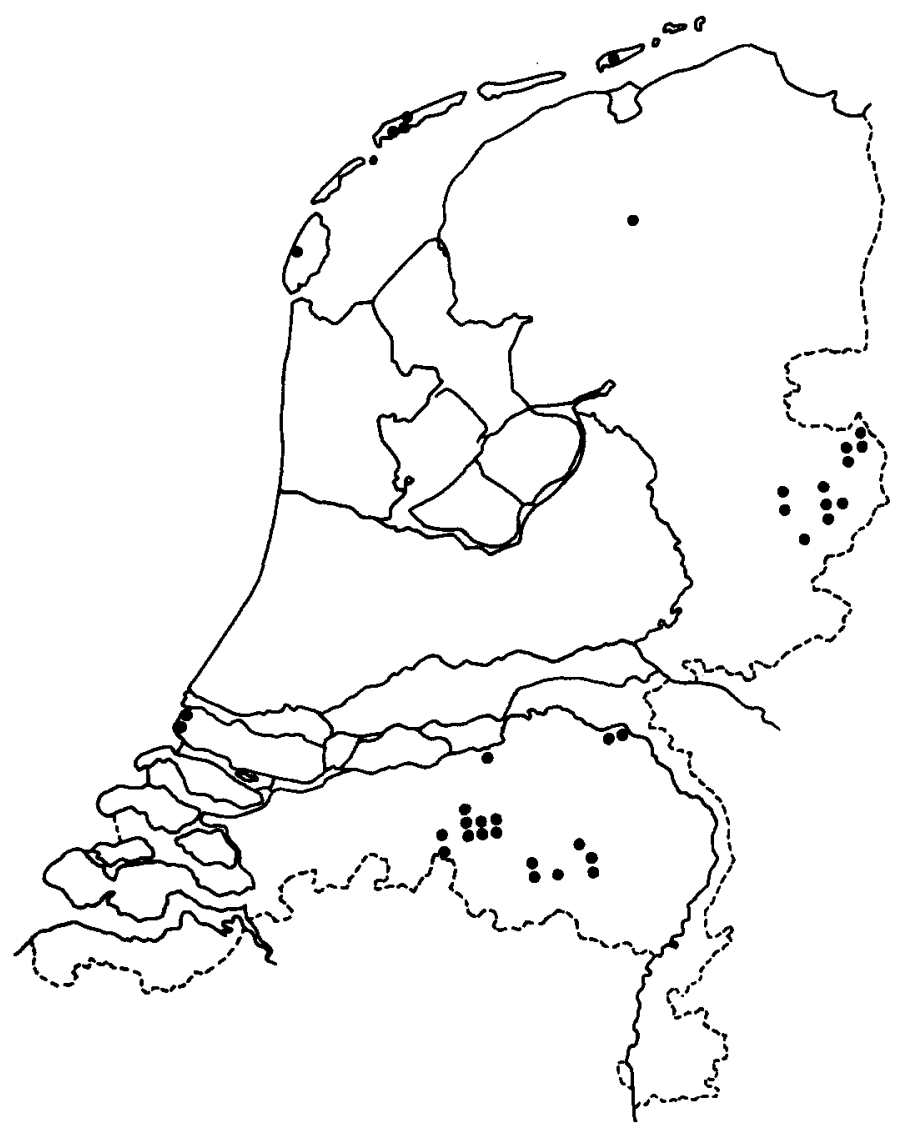

Fig. 1. Study areas. One dot may represent more than one investigated water. 


\section{MATERIALS AND METHODS}

During 1979 and 1980 each water was visited four times. On location, the floral composition was investigated and $\mathrm{pH}$-measurements were carried out with a Metrohm model E $488 \mathrm{pH}$-meter and a model EA 152 combined electrode. Alkalinity was estimated by titration of $100 \mathrm{ml}$ of water with 0.01 $\mathrm{M} \mathrm{HCl}$ down to $\mathrm{pH}$ 4.2. Water samples were taken in 200-ml iodated polyethylene bottles, immediately passed through a Whatman GF/C filter and fixed with $1 \mathrm{ml}$ of a $200 \mathrm{mg} \mathrm{l}^{-1} \mathrm{HgCl}_{2}$ solution. In the micro-habitats of each investigated plant species (Tables III and IV) sediment samples were taken with a brass tube (length $10 \mathrm{~cm}$, diameter $5.6 \mathrm{~cm}$ ). On each location 6 subsamples were taken and decanted into a 2-1 iodated polyethylene bottle. All samples were transported to the laboratory in a refrigerated container.

After arrival at the laboratory, the water samples were immediately frozen and stored at $-20^{\circ} \mathrm{C}$ until use. Redox potential measurements in the sediment samples were carried out within $24 \mathrm{~h}$ with a Metrohm model E 488 $\mathrm{pH} / \mathrm{mV}$ meter and a model EA 217 platinum electrode. For the analysis of the interstitial water $20 \mathrm{~g}$ of wet well-mixed sediment were weighed into a 400-ml conical flask and shaken on a Gerhardt model LS 20 shaker during $1 \mathrm{~h}$, after addition of $200 \mathrm{ml}$ bidistilled water. After centrifugation in a Heraeus Crist model 111 labofuge $(10 \mathrm{~min}, 5000$ r.p.m.) the acidity was estimated by titration of $50 \mathrm{ml}$ of the supernatant with $0.01 \mathrm{M} \mathrm{NaOH}$ up to pH 8.2. The alkalinity was estimated by titration of $50 \mathrm{ml}$ of the supernatant with $0.01 \mathrm{M} \mathrm{HCl}$ down to $\mathrm{pH} 4.2$. One-hundred $\mathrm{ml}$ of the supernatant was fixed by adding $0.5 \mathrm{ml}$ of a $200 \mathrm{mg} \mathrm{l} \mathrm{l}^{-1} \mathrm{HgCl}_{2}$ solution and stored at $-20^{\circ} \mathrm{C}$ until use. The water content of the sediment samples was estimated by weighing, drying $\left(24 \mathrm{~h}, 105^{\circ} \mathrm{C}\right)$ and reweighing. One-hundred $\mathrm{mg}$ of dried sediment were digested in a mixture of $0.5 \mathrm{ml}$ concentrated perchloric acid and $0.2 \mathrm{ml}$ sulphuric acid under pressure $\left(4 \mathrm{~h}, 170^{\circ} \mathrm{C}\right)$, according to Kotz et al. (1972), in order to obtain the elemental composition. For all samples, calcium was estimated with a Beckman model 1272 Atomic Absorption Spectrophotometer, sodium and potassium were estimated flame-photometrically using a Technicon I Auto Analyzer and colorimetrically with a Technicon II Auto Analyzer: orthophosphate according to Hendriksen (1965), nitrate according to Kamphake et al. (1967), ammonia according to Grasshoff and Johannsen (1977), chloride according to O'Brien (1962) and sulphate according to Technicon methodology (1981). The carbon dioxide content was calculated from acidity and that of hydrogen carbonate was calculated from alkalinity, both with a correction for $\mathrm{pH}$.

\section{RESULTS}

\section{Macrophyte composition}

In 1979 , only 15 ( $\sim 22 \%)$ of the 68 waters investigated, in which Littorella uniflora was one of the dominant species after 1950, were still dominated 
by this species; most of these stands occurred in the coastal region (Table Ia).

The 53 waters in which $L$. uniflora had disappeared or had strongly decreased can be divided into two groups. The major group (group 1: 41 waters) is characterized by the presence of submerged Juncus bulbosus and/ or Sphagnum spp. and a very low turbidity of the water (Table Ib). Twentyfive of these waters were dominated by J. bulbosus, 12 of them by Sphagnum spp. and in four of them no submerged plants were present except $J$. bulbosus and Sphagnum spp. in very small quantities. The waters of the minor group (group 2: 12 waters) are characterized by the absence of submerged J. bulbosus and/or Sphagnum spp. (Table Ic). Five of these waters were dominated by Myriophyllum alterniflorum DC, three of them by Riccia fluitans L. and Lemna minor L. and four of them were free of submerged macrophytes. In these last four waters the turbidity was very high as a result of luxurious plankton growth. Considerable differences were also noticed in the composition and coverage of the accompanying species (Tables $\mathrm{Ia}-\mathrm{c}$ ).

Eleocharis acicularis (L.) R. et S. is common and generally covered more than $5 \%$ of the bottom in the waters dominated by Littorella uniflora, it occurred only sporadically with a low coverage in waters dominated by $J$. bulbosus, and was absent in waters dominated by Sphagnum spp. In waters dominated by $\boldsymbol{M}$. alterniflorum, $\boldsymbol{E}$. acicularis showed a mean coverage and a frequency equal to those in waters dominated by $L$. uniflora, whereas $E$. acicularis was absent in waters dominated by Riccia fluitans and Lemna minor.

Luronium natans (L.) Raf. showed a similar pattern. It is common in waters dominated by Littorella uniflora, is less numerous in waters dominated by $J$. bulbosus and is scarce in waters dominated by Sphagnum spp. In the waters dominated by $M$. alterniflorum, Luronium natans is frequent, whereas in waters dominated by Riccia fluitans and Lemna minor it is absent.

Potamogeton gramineus $\mathrm{L}$. is restricted to waters dominated by Littorella uniflora. Polygonum amphibium L. and Eleocharis palustris (L.) R. et S. were both frequent in waters dominated by Littorella uniflora, M. alterniflorum and Riccia fluitans/Lemna minor; and were scarce in waters dominated by $J$. bulbosus and Sphagnum spp.

Carex rostrata Stokes and Eriophorum angustifolium Honck. occurred more frequently in the waters dominated by J. bulbosus. Eleocharis multicaulis (Sm.) Sm. was absent in waters dominated by Littorella uniflora (without $J$. bulbosus), $M$. alterniflorum and Riccia fluitans. Ranunculus peltatus Schrank and Elodea nuttallii (Planch.) St. John both occurred only in waters dominated by Myriophyllum alterniflorum. 


\section{TABLE Ia}

The floral composition of the waters in which Littorella uniflora was one of the dominant plant species in 1979-1980

\begin{tabular}{|c|c|c|c|}
\hline $\begin{array}{l}\text { Number } \\
\text { of waters }\end{array}$ & Dominant species & Accompanying species & Frequency* \\
\hline 11 & $\begin{array}{l}\text { Littorella uniflora } \\
\text { (L.) Aschers. }\end{array}$ & $\begin{array}{l}\text { Eleocharis acicularis (L.) R. et S. } \\
\text { Eleocharis palustris (L.) R. et S. } \\
\text { Hydrocotyle vulgaris L. } \\
\text { Echinodorus ranunculoides (L.) } \\
\quad \text { Engelman } \\
\text { Luronium natans (L.) Raf. } \\
\text { Potamogeton gramineus L. } \\
\text { Ranunculus flammula L. } \\
\text { Carex rostrata Stokes } \\
\text { Elatine hexandra (Lapierre) DC } \\
\text { Myosotis scorpioides L. } \\
\text { Peplis portula L. } \\
\text { Polygonum amphibium L. } \\
\text { Chara globularis Thuill. } \\
\text { Carex lasiocarpa Ehrh. } \\
\text { Echinodorus repens (Lamk.) Kern } \\
\quad \text { et Reichg. } \\
\text { Myriophyllum alterniflorum DC } \\
\text { Eriophorum angustifolium Honck. } \\
\text { Hypericum elodes L. } \\
\text { Menyvanthes trifoliata L. } \\
\text { Nuphar lutea (L.) Sm. } \\
\text { Ranunculus ololeucos Lloyd }\end{array}$ & $\begin{array}{l}7+ \\
6 \\
6 \\
5 \\
5+ \\
5+ \\
5 \\
4 \\
4+ \\
4 \\
3 \\
3+ \\
2 \\
2 \\
2 \\
2 \\
1 \\
1 \\
1 \\
1 \\
1\end{array}$ \\
\hline 4 & $\begin{array}{l}\text { Littorella uniflora } \\
\text { (L.) Aschers. and } \\
\text { Juncus bulbosus L. }\end{array}$ & $\begin{array}{l}\text { Hydrocotyle vulgaris L. } \\
\text { Sphagnum spp. } \\
\text { Carex rostrata Stokes } \\
\text { Eleocharis multicaulis (Sm.) Sm. } \\
\text { Eleocharis palustris (L.) R. et S. } \\
\text { Lobelia dortmanna L. } \\
\text { Ranunculus flammula L. } \\
\text { Echinodorus repens (Lamk.) Kern } \\
\quad \text { et Reichg. } \\
\text { Hypericum elodes L. } \\
\text { Luronium natans (L.) Raf. } \\
\text { Isoëtes lacustris L. }\end{array}$ & $\begin{array}{l}3 \\
3+ \\
2 \\
2+ \\
2 \\
2 \\
2 \\
1 \\
1 \\
1+ \\
1+\end{array}$ \\
\hline
\end{tabular}

*Frequency: the number of waters in which the species was present. Species marked with + often had a coverage of $>5 \%$. 


\section{TABLE Ib}

The floral composition of the waters in which Littorella uniflora was not one of the dominant species and in which submerged Juncus bulbosus and/or Sphagnum occurred in $1979-1980$

\begin{tabular}{llll}
\hline $\begin{array}{l}\text { Number } \\
\text { of waters }\end{array}$ & Dominant species & Accompanying species & Frequency
\end{tabular}

\begin{tabular}{|c|c|c|c|}
\hline 25 & Juncus bulbosus L. & $\begin{array}{l}\text { Sphagnum spp. } \\
\text { Carex rostrata Stokes } \\
\text { Hypericum elodes L. } \\
\text { Eleocharis palustris (L.) R. et S. } \\
\text { Hydrocotyle vulgaris L. } \\
\text { Luronium natans (L.) Raf. } \\
\text { Eriophorum angustifolium Honck. } \\
\text { Utricularia minor L. } \\
\text { Nymphaea alba L. } \\
\text { Ranunculus flammula L. } \\
\text { Ranunculus ololeucos Lloyd } \\
\text { Peplis portula L. } \\
\text { Potamogeton natans L. } \\
\text { Carex lasiocarpa Ehrh. } \\
\text { Echinodorus ranunculoides (L.) } \\
\text { Engelman } \\
\text { Eleocharis acicularis (L.) R. et S. } \\
\text { Menyanthes trifoliata L. } \\
\text { Nuphar lutea (L.) Sm. } \\
\text { Polygonum amphibium L. }\end{array}$ & $\begin{array}{l}12+ \\
11+ \\
8 \\
8 \\
7 \\
7 \\
7+ \\
7+ \\
6 \\
6 \\
6 \\
6 \\
6 \\
2+ \\
2 \\
2 \\
1 \\
1 \\
1\end{array}$ \\
\hline 12 & $\begin{array}{l}\text { Sphagnum spp. } \\
\text { (most S. cuspidatum } \\
\text { Hoffm.) }\end{array}$ & $\begin{array}{l}\text { Carex rostrata Stokes } \\
\text { Eriophorum angustifolium Honck. } \\
\text { Hydrocotyle vulgaris L. } \\
\text { Eleocharis multicaulis (Sm.) Sm. } \\
\text { Utricularia minor L. } \\
\text { Eleocharis palustris (L.) R. et S. } \\
\text { Menyanthes trifoliata L. } \\
\text { Hypericum elodes L. } \\
\text { Ranunculus flammula L. } \\
\text { Carex lasiocarpa Ehrh. } \\
\text { Juncus articulatus L. } \\
\text { Luronium natans (L.) Raf. } \\
\text { Nymphaea alba L. } \\
\text { Polygonum amphibium L. }\end{array}$ & $\begin{array}{l}10+ \\
9+ \\
8 \\
6 \\
5+ \\
4 \\
4 \\
4 \\
4 \\
3 \\
3 \\
2 \\
2 \\
2\end{array}$ \\
\hline 4 & \multicolumn{3}{|c|}{$\begin{array}{l}\text { Clear water } \\
\text { no submerged macrophytes } \\
\text { except Juncus bulbosus and Sphagnum spp. in very small quantities }\end{array}$} \\
\hline
\end{tabular}


TABLE Ic

The floral composition of the waters in which Littorella uniflora was not one of the dominant species and in which no submerged Juncus bulbosus and/or Sphagnum spp. occurred in 1979-1980

\begin{tabular}{|c|c|c|c|}
\hline $\begin{array}{l}\text { Number } \\
\text { of waters }\end{array}$ & Dominant species & Accompanying species & Frequency \\
\hline 5 & $\begin{array}{l}\text { Myriophyllum } \\
\text { alterniflorum DC }\end{array}$ & $\begin{array}{l}\text { Eleocharis palustris (L.) R. et S. } \\
\text { Hydrocotyle vulgaris L. } \\
\text { Littorella uniflora (L.) Aschers. } \\
\text { Luronium natans (L.) Raf. } \\
\text { Myosotis scorpioides L. } \\
\text { Ranunculus peltatus Schrank } \\
\text { Ranunculus flammula L. } \\
\text { Apium inundatum (L.) Rehb.f. } \\
\text { Chara globularis Thuill. } \\
\text { Eleocharis acicularis (L.) R. et S. } \\
\text { Echinodorus ranunculoides (L.) } \\
\quad \text { Engelman } \\
\text { Elatine hexandra (Lapierre) DC } \\
\text { Nuphar lutea (L.) Sm. } \\
\text { Polygonum amphibium L. } \\
\text { Nymphaea alba L. } \\
\text { Peplis portula L. } \\
\text { Elodea nuttallii (Planch.) St. John }\end{array}$ & $\begin{array}{l}5+ \\
4 \\
4+ \\
4+ \\
4 \\
4+ \\
4 \\
2 \\
2+ \\
2+ \\
2 \\
2+ \\
2 \\
2+ \\
1 \\
1 \\
1\end{array}$ \\
\hline 3 & $\begin{array}{l}\text { Riccia fluitans } \mathrm{L} \text {. } \\
\text { Lemna minor } \mathrm{L} \text {. }\end{array}$ & $\begin{array}{l}\text { Lemna trisulca L. } \\
\text { Eleocharis palustris (L.) R. et S. } \\
\text { Hydrocotyle vulgaris } \mathrm{L} . \\
\text { Myosotis scorpioides } \mathrm{L} . \\
\text { Nuphar lutea (L.) Sm. } \\
\text { Ranunculus flammula L. } \\
\text { Rorippa amphibia (L.) Besser } \\
\text { Peplis portula L. }\end{array}$ & $\begin{array}{l}3+ \\
2 \\
2 \\
2 \\
2+ \\
2 \\
2 \\
1\end{array}$ \\
\hline 4 & $\begin{array}{r}\text { Turbid water (algal } \\
\text { no submerged } \mathrm{m}\end{array}$ & 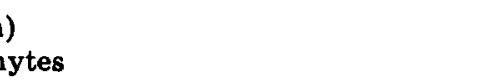 & \\
\hline
\end{tabular}

Frequency: the number of waters in which the species was present. Species marked with + often had a coverage $>5 \%$.

\section{Chemistry of water and sediments}

\section{Water chemistry}

The results are shown in Table II. Waters dominated by Littorella uniflora had a mean alkalinity of 0.50 meq. $1^{-1}$ and those dominated by J. bulbosus of 0.02 meq. $1^{-1}$; however, it has to be noted that most waters with J. bulbosus as a dominant species had no buffer capacity at all. The waters dominated by Sphagnum spp. had a mean alkalinity of 0.01 meq. $1^{-1}$, those dominat- 


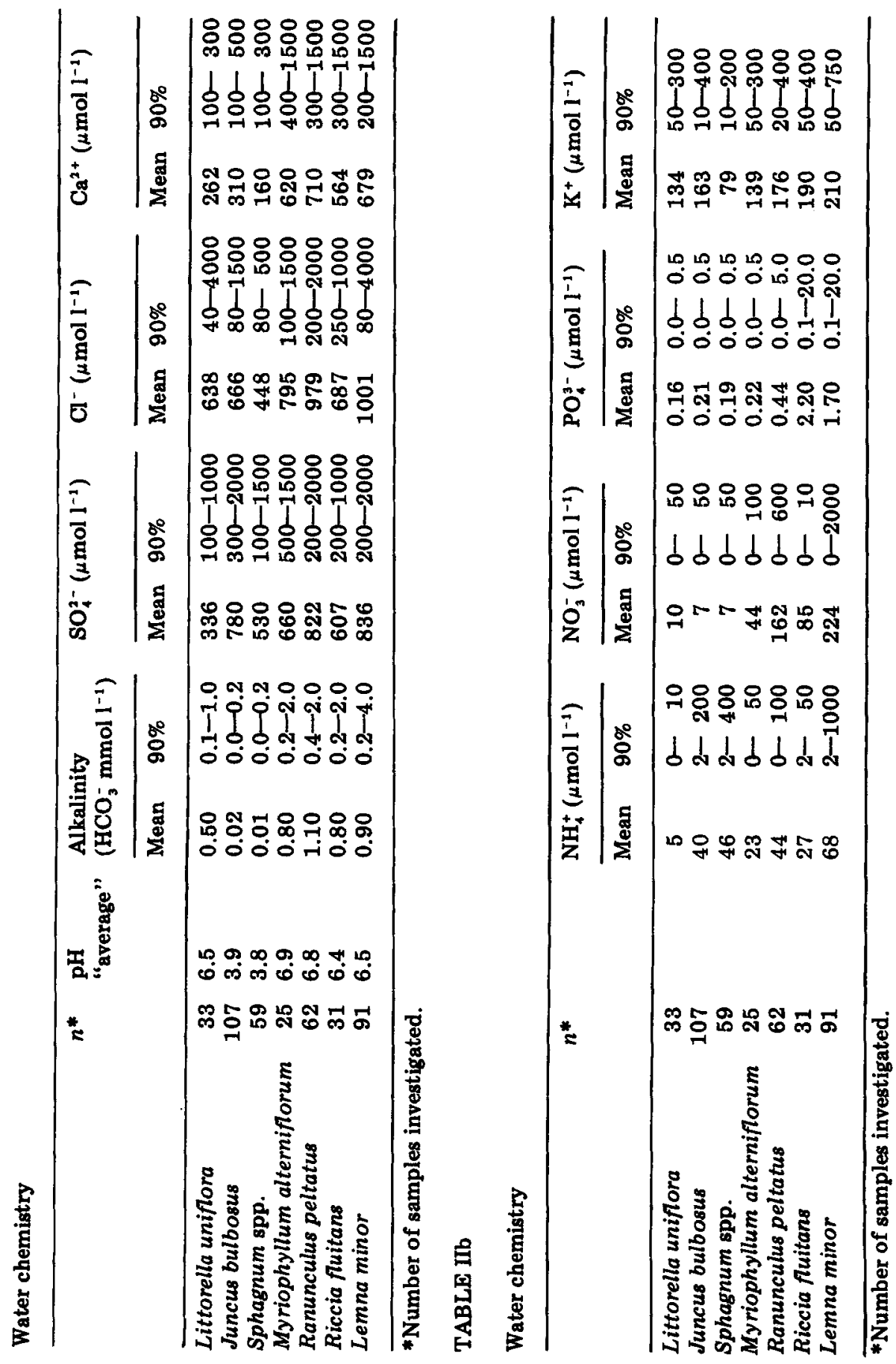


ed by $M$. alterniflorum and Riccia fluitans and/or Lemna minor had a mean alkalinity of 0.80 meq. $1^{-1}$, thus higher than that of the Littorella-dominated waters. From the investigated plant species, J. bulbosus and Sphagnum spp. occurred mainly in acid waters (pH on an "average" 3.8 ) while the other species mostly occur in circumneutral waters.

The mean sulphate concentration was the lowest in waters dominated by Littorella uniflora and clearly higher in the waters dominated by J. bulbosus, $M$. alterniflorum and $R$. fluitans. The mean ammonium concentration was low in the waters dominated by $L$. uniflora and clearly higher in the waters dominated by $J$. bulbosus and Sphagnum spp. However, the mean nitrate concentration was the lowest in waters dominated by J. bulbosus and Sphagnum spp., somewhat higher in waters dominated by $L$. uniflora, and much higher in the waters dominated by $M$. alterniflorum and $R$. fluitans.

The mean concentrations of ortho-phosphate were practically identical in the waters dominated by $L$. uniflora, J. bulbosus, Sphagnum spp. and $M$. alterniflorum and much higher in waters dominated by $R$. fluitans and Lemna minor.

The mean concentrations of potassium, calcium and chloride did not differ much in the investigated waters, except for waters dominated by Sphagnum spp., in which they were lower, and for waters dominated by $M$. alterniflorum, in which they were higher.

\section{Sediment analysis (Tables III and IV)}

The mean $\mathrm{HCO}_{3}^{-}$concentration of the interstitial water was the lowest for J. bulbosus, somewhat higher for Sphagnum spp. and Littorella uniflora and much higher for $M$. alterniflorum and $R$. fluitans.

The mean $\mathrm{CO}_{2}$ concentration, however, was the highest for $J$. bulbosus and Sphagnum spp., clearly lower for $M$. alterniflorum and the lowest for L. uniflora.

The mean concentrations of ortho-phosphate in the interstitial waters were almost equal for $L$. uniflora, J. bulbosus and Sphagnum spp. and clearly higher for $M$. alterniflorum and $R$. fluitans. The mean nitrate concentration was the highest for L. uniflora, lower for J. bulbosus and Sphagnum spp. and much lower for Lemna minor and $R$. fluitans.

The mean ammonium concentrations, however, were the lowest for Littorella uniflora, higher for J. bulbosus and Sphagnum spp. and the highest for Lemna minor and $R$. fluitans.

The mean calcium concentration was almost equal for Littorella uniflora, $J$. bulbosus and Sphagnum spp. and much higher for $M$. alterniflorum, $R a$ nunculus peltatus, Lemna minor and Riccia fluitans.

The mean total $\mathrm{N}$ concentration in the sediment was the lowest for Litto rella uniflora, somewhat higher for $J$. bulbosus and $M$. alterniflorum and much higher for Sphagnum spp., Lemna minor and $R$. fluitans.

The mean total $P$ concentration also was the lowest for Littorella uniflora, higher for $J$. bulbosus, Sphagnum spp., M. alterniflorum, $R$. fluitans and the highest for Lemna minor. 


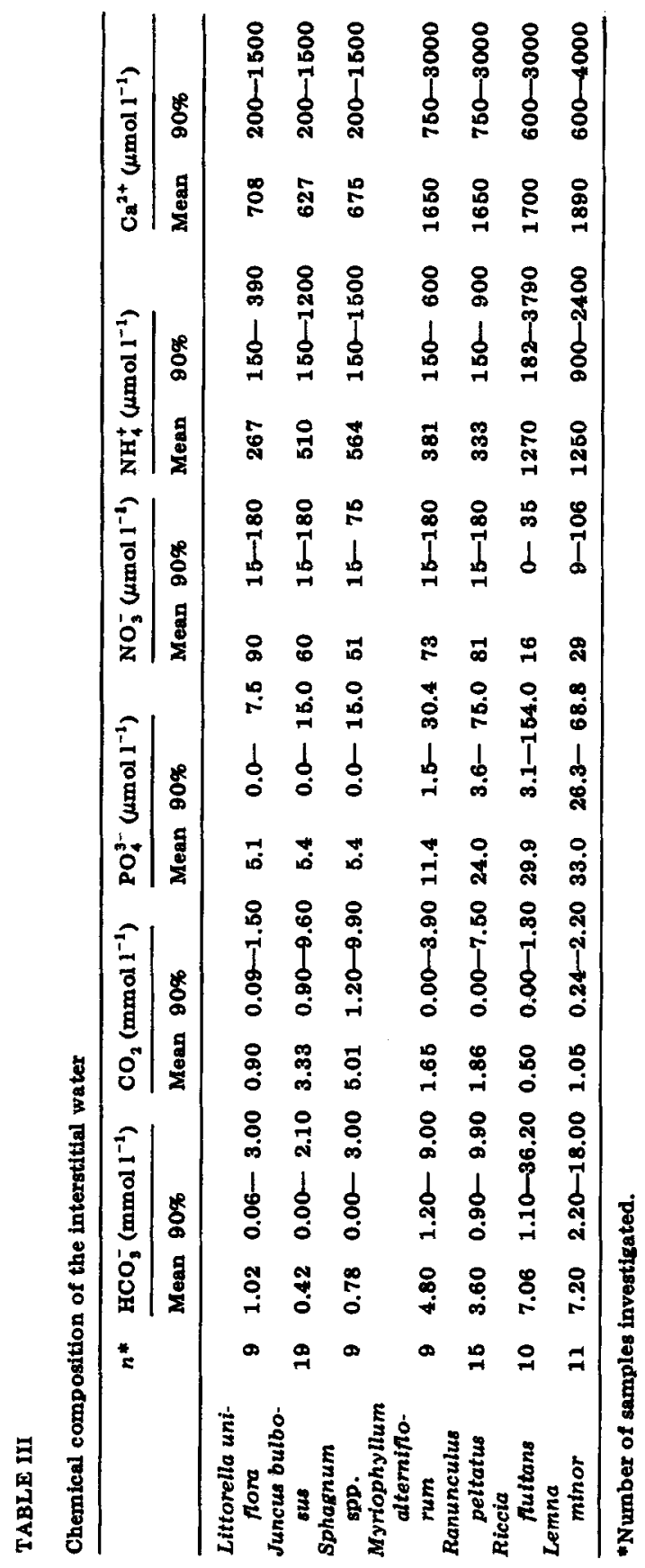




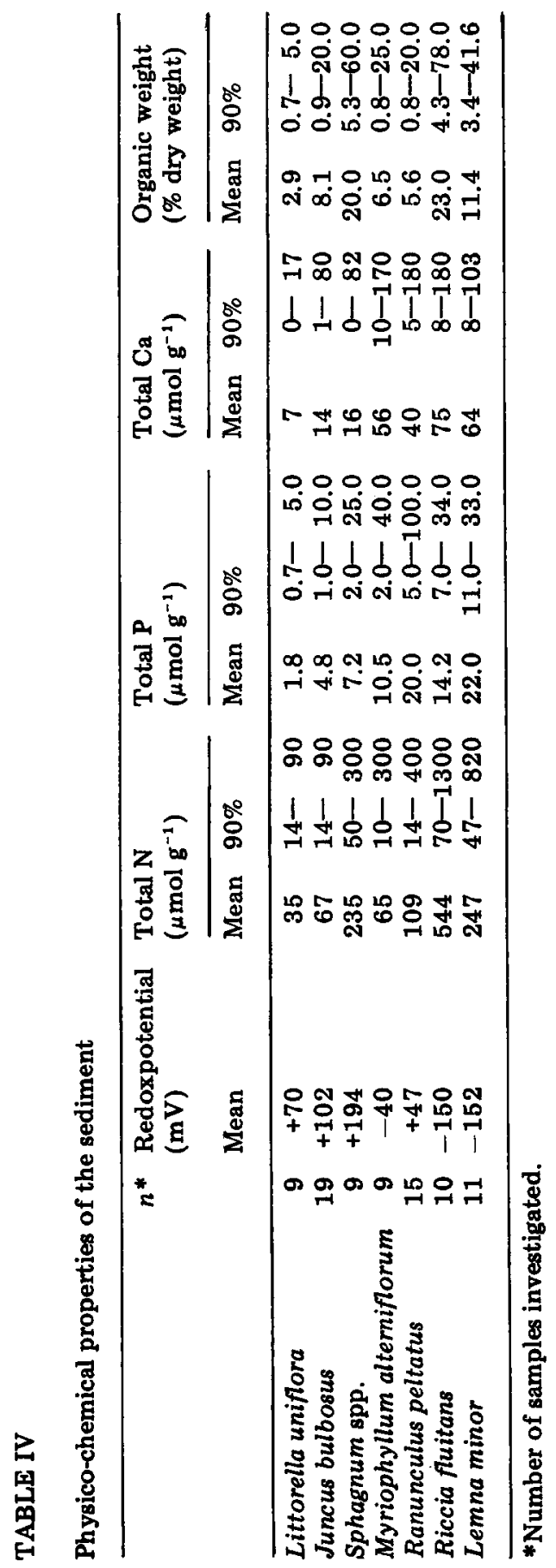


The mean total $\mathrm{Ca}$ concentrations show similar results: the lowest for Littorella uniflora and the highest for $R$. fluitans.

The mean organic weight of the sediment was the lowest for $L$. uniflora, followed by Ranunculus peltatus, $M$. alterniflorum and J. bulbosus and much higher for Sphagnum spp. and Riccia fluitans.

\section{DISCUSSION}

All observations indicate that acidification of the water caused by acid precipitation leads to a decrease and finally to a disappearance of Littorella uniflora and other "Littorellion"-species, coincident with the appearance and often luxurious growth of J. bulbosus, Sphagnum spp., Eleocharis multicaulis, Eriophorum angustifolium, etc. (Table Ib). The $\mathrm{pH}$ of the water declines strongly, on an average from $\mathrm{pH} 6.5$ for $L$. uniflora down to $\mathrm{pH} 3.8$ for $J$. bulbosus and Sphagnum spp. Alkalinity decreases on an average from 0.50 meq. $~^{-1}$ for $L$. uniflora down to 0.02 and 0.01 meq. $1^{-1}$ for J. bulbosus and Sphagnum spp., respectively Wiegleb (1978) mentions similar data for waters in the Federal German Republic: a mean alkalinity of 0.50 meq. $\mathrm{l}^{-1}$ for $L$. uniflora and 0.05 meq. $~^{-1}$ for $J$. bulbosus. Sand-Jensen and Rasmussen (1978) also found $J$. bulbosus to be the only vascular plant species in strongly acidified Scandinavian waters and Nilssen (1980) mentions a luxurious growth of $J$. bulbosus in acidified waters in Norway. Grahn et al. (1974) and Grahn (1977) mention a suppression of isoetid species in Scandinavian waters by luxurious Sphagnum growth as a result of acidification of the water. Investigations by Spence $(1964,1967)$ clearly show that "Littorellion" species such as $L$. uniflora and Lobelia dortmanna mainly occur in non-acid, poorly buffered waters.

Acidification of the water brings about not one, but a number of changes in the physical and chemical properties of water and sediment, and it is difficult to establish which of these is responsible for the changes in the macrophyte composition. For instance, the sulphate concentration in J. bulbosusdominated, acidified waters on an average is more than twice as high as in non-acidified Littorella uniflora-dominated waters, probably due to precipitation containing sulphuric acid and a possibly reduced sulphate reduction, though it is doubtful whether these sulphate concentrations have any influence on the observed changes in the macrophyte composition, as the maximum $\mathrm{SO}_{4}^{2-}$ concentration at which $L$. uniflora occurs is considerably higher than the mean $\mathrm{SO}_{4}^{2-}$ concentration for $J$. bulbosus.

There are also changes in the nitrogen and phosphorus concentrations. The total amount of mineral nitrogen in waters dominated by $J$. bulbosus and Sphagnum spp. (including the interstitial water) is on an average much higher than in waters dominated by $L$. uniflora, but whether this is of any importance is doubtful, as phosphorus is normally the limiting factor in moorland pools (Table IIb).

In particular, the mean ammonium concentrations of water and interstitial 
water in acidified $J$. bulbosus and Sphagnum spp. dominated water bodies are much higher, undoubtedly due to the strongly decreased nitrification as a result of the low $\mathrm{pH}$.

Whether these high ammonium concentrations are toxic to $L$. uniflora under these circumstances has to be doubted. It is true that ammonium toxicity to various species of aquatic macrophytes has been reported (Glänzer et al., 1977), but these experiments were carried out at a relatively high $\mathrm{pH}$, at which part of the ammonium occurs as toxic $\mathrm{NH}_{3}$ (Warren, 1962). However, the $\mathrm{pH}$ in the acidified waters is low enough to keep all ammonium as nontoxic $\mathrm{NH}_{4}^{+}$. Possibly, however, differences among the various plant species may occur in the ability to use ammonium instead of nitrate as a nitrogen source.

The mean concentration of ortho-phosphate in the water as well as in the interstitial water is almost equal in L. uniflora-, J. bulbosus- and Sphagnum spp.-dominated waters. Therefore, it is not to be expected that the changes in the macrophyte composition are due to changes in the phosphate budget, although the mean total $P$ concentration in the upper sediment layer of the acidified waters is clearly higher than in the non-acidified waters. The accumulation of organic material as a result of strongly decreased microbial activity could partly be responsible, just as the strongly increased redox potential in the upper sediment layer, which leads to accumulation of phosphate coming from the deeper, anaerobic sediment layers. The latter process has been described by Damman (1978) for ombrotrophic peat bogs.

It is likely that the tremendous changes in the inorganic carbon content which occur as a result of acidification, play a very important role. In acidifying waters the inorganic carbon content of the water decreases to practically zero and the submerged macrophytes fully depend on the sediment, as the diffusion of $\mathrm{CO}_{2}$ from the air into stagnant acid water is insufficient. Sand-Jensen and S申ndergaard (1979) discovered that the size of $L$. uniflora plants in water poor in $\mathrm{CO}_{2}$ depends on the $\mathrm{CO}_{2}$ level in the sediment.

The data presented here clearly show that in acidified waters dominated by $J$. bulbosus the mean $\mathrm{CO}_{2}$ concentration of the interstitial water is much higher than in non-acidified, $L$. uniflora-dominated waters. The $\mathrm{CO}_{2}$ concentration of the interstitial water is highest in the Sphagnum spp.-dominated waters. This increase of $\mathrm{CO}_{2}$ is no doubt due to the acid water layer acting upon the $\mathrm{HCO}_{3}^{-}$and $\mathrm{CO}_{3}^{2-}$ in the sediment. This leads to the hypothesis that changes in the macrophyte composition are mainly dependent on the changes in the $\mathrm{CO}_{2}$ concentration in the sediment, which depends on the $\mathrm{HCO}_{3}^{-}$content of the interstitial water and the $\mathrm{CO}_{3}^{2-}$ content of the sediment. Field observations support this hypothesis. In acidifying dune pools above relatively $\mathrm{CO}_{3}^{2-}$-rich sediments (e.g. van Hünenplak, Terschelling) the very tall Littorella plants became fully overgrown by Sphagnum spp., whereas in acidifying moorland pools above relatively $\mathrm{CO}_{3}^{2-}$-poor sediments (e.g., Groothuisven near Tilburg) $L$. uniflora and Lobelia dortmanna became overgrown by $J$. bulbosus. 
In other acidifying moorland pools, above mainly $\mathrm{CO}_{3}^{2-}$-free sediments (e.g., Staalbergven near Oisterwijk; Galgenven near Tilburg) Littorella uniflo$r a$ and Luronium natans gradually became smaller and almost disappeared, without any other macrophyte species appearing in their place.

Carbon dioxide measurements in the interstitial water of these locations also confirmed the above hypothesis. There is also an explanation for the fact that in some places "Littorellion" communities can persist for a very long period after acidification, as was observed in a few cases during this study and has also been mentioned by Pietsch (1972) for some waters in Central Europe. Luxurious growth of $J$. bulbosus and Sphagnum spp. can only occur after an increased $\mathrm{CO}_{2}$ level in the sediment when phosphate or nitrogen are not limiting.

Eutrophication, in its classical meaning (increased input of nutrients such as phosphate and nitrogen), often mentioned as the main cause of the disappearance or decline of "Littorellion" species (Schoof-van Pelt, 1973; Pietsch, 1977; Wittig, 1980), has been a less important factor in the investigated waters during the last 30 years than acidification.

A change in the phosphate content seems to be responsible for the changes in all 12 waters where "Littorellion" species had strongly declined or had disappeared and no submerged Sphagnum spp. or J. bulbosus occurred. A phosphate enrichment of the mineral soil, with a strongly increased amount of ortho-phosphate in the interstitial water, but hardly any increased amount of phosphate in the water (e.g., environments rich in iron) leads to luxurious growth of submerged macrophytes, mainly $M$. alterniflorum and/or Ranunculus peltatus and a suppression of "Littorellion" species. However, after a number of years of luxurious plant growth the submerged plant species disappear again because the sediment becomes more or less organic. It is not clearly understood which processes underlie this phenomenon. Possibly the strongly lowered redox potential and the concomitantly strongly decreased $\mathrm{CO}_{2}$ and strongly increased $\mathrm{NH}_{4}^{+}$concentration of the sediment which are found under these circumstances are responsible (Tables III and IV). A phosphate enrichment of the system with a clearly increased ortho-phosphate concentration not only in the sediment, but also in the water leads to luxurious growth of non-rooted macrophytes such as Riccia fluitans and Lemna minor in small, shallow waters. In larger and deeper water bodies the water becomes turbid as a result of algal bloom and/or strong development of epiphytes on the macrophytes. In this case, light reduction seems to be responsible for the decrease or disappearance of the submerged macrophytes (Sand-Jensen and S $\phi$ ndergaard, 1981).

In order to support the preceding hypotheses, and to obtain causal relations between the changes in the physico-chemical environment and plant development, "in vitro" eco-physiological and culture experiments have been carried out with the plant species involved. The results of these experiments will be discussed in part II of this study. 


\section{ACKNOWLEDGEMENTS}

The author thanks W.A. Allebes, F. Bloemendaal, L. Meuffels, J.A.A.R. Schuurkes and P.P.M. Thissen for their assistance during the investigations, Mrs. M. van Kuppeveld-Kuiper who typed the manuscript and Mrs. J.M.A. Roelofs-Hendriks and Prof. Dr. C. den Hartog who critically read the text.

\section{REFERENCES}

Alexander, M., 1980. Effects of acid precipitation on biochemical activities in soil. In: D. Drablфs and A. Tollan (Editors), Proc. Int. Conf. Ecol. Impact Acid Precipitation, Oslo, Norway. S.N.S.F. Project, pp. 47-52.

Damman, A.W.H., 1978. Distribution and movement of elements in ombrotrophic peat bogs. Oikos, $30: 480-495$.

Daye, P.G. and Garside, E.T., 1975. Lethal levels of $\mathrm{pH}$ for brooktrout, Savelinus fontinalius (Mitchell). Can. J. Zool., 101: 639-641.

Dochinger, L.S. and Seliga, T.A., 1975. Acid precipitation and the forest ecosystem. Report from the First International Symposium. J. Air Pollut. Control Assoc., 25: 11031105.

Drablфs, D. and Tollan, A. (Editors), 1980. Proc. Int. Conf. Ecol. Impact Acid Precipitation. S.N.S.F. Project, Oslo, 383 pp.

Engstrom, A., 1971. Report of the Swedish Preparatory Committee for the U.N. Conference on the Human Environment, Stockholm.

Glänzer, U., Haber, W. and Kohler, A., 1977. Experimentelle Untersuchungen zur Belastbarkeit submerser Fliessgewässer-Makrophyten. Arch. Hydrobiol., 79: 193-232.

Grahn, O., 1977. Macrophyte succession in Swedish lakes caused by deposition of airborne substances. Water, Air Soil Pollut., 7: 295-305.

Grahn, O., Hultberg, H. and Landner, J., 1974. Oligotrophication - a self-accelerating process in lakes subjected to excessive supply of acid substances. Ambio, 3: 93-94.

Grasshoff, K. and Johannsen, H., 1977. A new sensitive method for the determination of ammonia in sea water. Water Res., $2: 516$.

Hendriksen, A., 1965. An automated method for determining low-level concentrations of phosphate in fresh and saline waters. Analyst (London), 90: 29-34.

Kamphake, L.J., Hannah, S.A. and Cohen, J.M., 1967. Automated analysis for nitrate by hydrazine reduction. Water Res., 1: 205-206.

Kotz, L., Kaizer, G., Schölpel, T. and Tölg, G., 1972. Aufschluss biologischer Matrices für die Bestimmung sehr niedriger Spurenelementgehälte bei begrenster Einwaage mit Salpetersäure unter Druck in einem Teflongefäss. Z. Anal. Chem., 260: 207-209.

Nilssen, J.P., 1980. Acidification of a small watershed in southern Norway and some characteristics of acidic aquatic environments. Int. Rev. Gesamten Hydrobiol. Hydrogr., 65: 177-207.

O'Brien, J., 1962. Automatic analysis of chlorides in sewage wastes. Engineering, 33: 670-672.

Pietsch, W., 1972. Ausgewählte Beispiele für Indikatoreigenschaften höherer Wasserpflanzen. Arch. Naturschutz Landschaftsforsch., 12: 121-151.

Pietsch, W., 1977. Beitrag zur Soziologie und Ökologie der europäischen Littorelletea und Utricularietea Gesellschaften. Feddes Repert. Bot. Taxon. Geobot., 88: 141-245.

Pott, R., 1982. Littorelletea-Gesellschaften in der Westfälischen Bucht. Tuexenia, 2: 3145.

Sand-Jensen, K. and Rasmussen, L., 1978. Macrophytes and chemistry of acidic streams from Lignite mining areas. Bot. Tidsskr., 72: 105-112.

Sand-Jensen, K. and S $\phi$ ndergaard, M., 1979. Distribution and quantitative development of aquatic macrophytes in relation to sediment characteristics in oligotrophic Lake Kalgaard, Denmark. Freshwater Biol., 9: 1-11. 
Sand-Jensen, K. and S $\phi$ ndergaard, M., 1981. Phytoplankton and epiphy te development and their shading effect on submerged macrophytes in lakes of different nutrient status. Int. Rev. Gesamten Hydrobiol. Hydrogr., 66: 529-552.

Schoof-van Pelt, M.M., 1973. Littorelletea, a study of the vegetation of some amphiphytic communities of Western Europe. Ph.D. Thesis, Nijmegen, 216 pp.

Spence, D.H.N., 1964. The macrophyte vegetation of freshwater lochs, swamps and associated fens. In: J.H.S. Burnett (Editor), The Vegetation of Scotland. Edinburgh/ London, pp. 306-425.

Spence, D.H.N., 1967. Factors controlling the distribution of freshwater macrophytes with particular reference to the lochs of Scotland. J. Ecol., 55: 147-170.

Stuanes, A.O., 1980. Effect of acid precipitation on soil and forest soil due to artificial rain of varying acidity. In: D. Drablфs and A. Tollan (Editors), Proc. Int. Conf. Ecol. Impact Acid Precipitation, Oslo, Norway. S.N.S.F. Project, pp. 152-155.

Tamm, C.O., Wiklander, G. and Popovic, G., 1977. Effects of application of sulphuric acid to poor pine forests. Water, Air Soil Pollut., 8: 75.

Technicon Auto Analyzer Methodology, 1981. Industrial Method 635-81W, New York, $8 \mathrm{pp}$.

Van Dam, H. and Kooyman-van Blokland, H., 1978. Man-made changes in some Dutch moorland pools, as reflected by historical and recent data about diatoms and macrophytes. Int. Rev. Gesamten Hydrobiol. Hydrogr., 63: 387-607.

Van Dam, J., Suurmond, G. and ter Braak, J.F., 1981. Impact of acidification on diatoms and chemistry of Dutch moorland pools. Hydrobiologia, 83: 425-459.

Van Zellem, J., 1981. De verzuring van de regen. Natura, 78: 326-333.

Vangenechten, J.H.D., van Puymbroeck, S., van der Borght, O.L.J., Bosmans, F. and Deckers, H., 1980. Physico-chemistry of surface waters in the Campine region of Belgium, with special reference to acid moorland pools. Arch. Hydrobiol., 90: 369396.

Voigt, G.K., 1979. Proc. Impact of Intensive Harvesting on Forest Nutrient Cycling. State University New York, Syracuse, pp. 33-48.

Warren, K.S., 1962. Ammonia toxicity and pH. Nature, $195:$ 4 7-49.

Westhoff, V., 1979. Bedrohung und Erhaltung seltener Pflanzengesellschaften in den Niederlanden. In: $O$. Wilmanns and $R$. Tüxen (Editors), Werden und Vergehen von Pflanzengesellschaften. J. Cramer, Vaduz, pp. 285-313.

Westhoff, V., Bakker, P.A., van Leeuwen, C.G.V. and van der Voo, E.E., 1971. Wilde Planten. Flora en vegetatie in onze natuurgebieden. 2: Het lage land. Ver. Beh. Natuurmon. Nederland, 304 pp.

Westhoff, V., Bakker, P.A., van Leeuwen, C.G.V. and van der Voo, E.E., 1973. Wilde Planten. Flora en vegetatie in onze natuurgebieden. 3: De hoge zandgronden. Ver. Beh. Natuurmon. Nederland, 359 pp.

Wiegleb, G., 1978. Untersuchungen über den Zusammenhang zwischen hydrochemischen Umweltfaktoren und Makrophytenvegetationen in stehenden Gewässer. Arch. Hydrobiol., 83 : 443-484.

Wittig, R., 1980. Die geschützten Moore, und oligotrophen Gewässer der Westfälischen Bucht. Schriftenreihe der Landesanstalt für Ökologie, Landschaftsentwicklung und Forstplanung Nordrhein-Westfalen, 5: 1-228.

Wittig, R., 1982a. The effectiveness of the protection of endangered oligotrophic-water vascular plants in nature conservation areas of Northrhine-Westphalia. In: J.J. Symoens, S.S. Hooper and P. Compère (Editors), Studies on Aquatic Vascular Plants. R. Bot. Soc. Brussels, Belgium, pp. 418-424.

Wittig, R., 1982b. Verbreitung der Littorelletea-Arten in der Westfälischen Bucht - Decheniana (Bonn), 135: 14-21.

Wittig, R. and Pott, R., 1982. Dot-grid-maps of the distribution (1976-1980) of Littorelletea-species in the "Westfälische Bucht" (North-Rhine-Westphalia, Federal Republic of Germany.) In: J.J. Symoens, S.S. Hooper and P. Compère (Editors), Studies on Aquatic Vascular Plants. R. Bot. Soc. Brussels, Belgium, pp. 412-417. 